\title{
Effek Imunostimulator Kubis (Brassica Oleracea Var. Capitata Alba) Terhadap Titer Imunoglobulin G (Ig G) Pada Kelinci Yang Diinduksi Dengan Sel Darah Merah Domba
}

\author{
Nurul Inayati' ${ }^{1}$, Fihiruddin ${ }^{2}$, I Wayan Getas ${ }^{3}$ \\ 1,2,3 Poltekkes Kemenkes Mataram Jurusan Analis Kesehatan
}

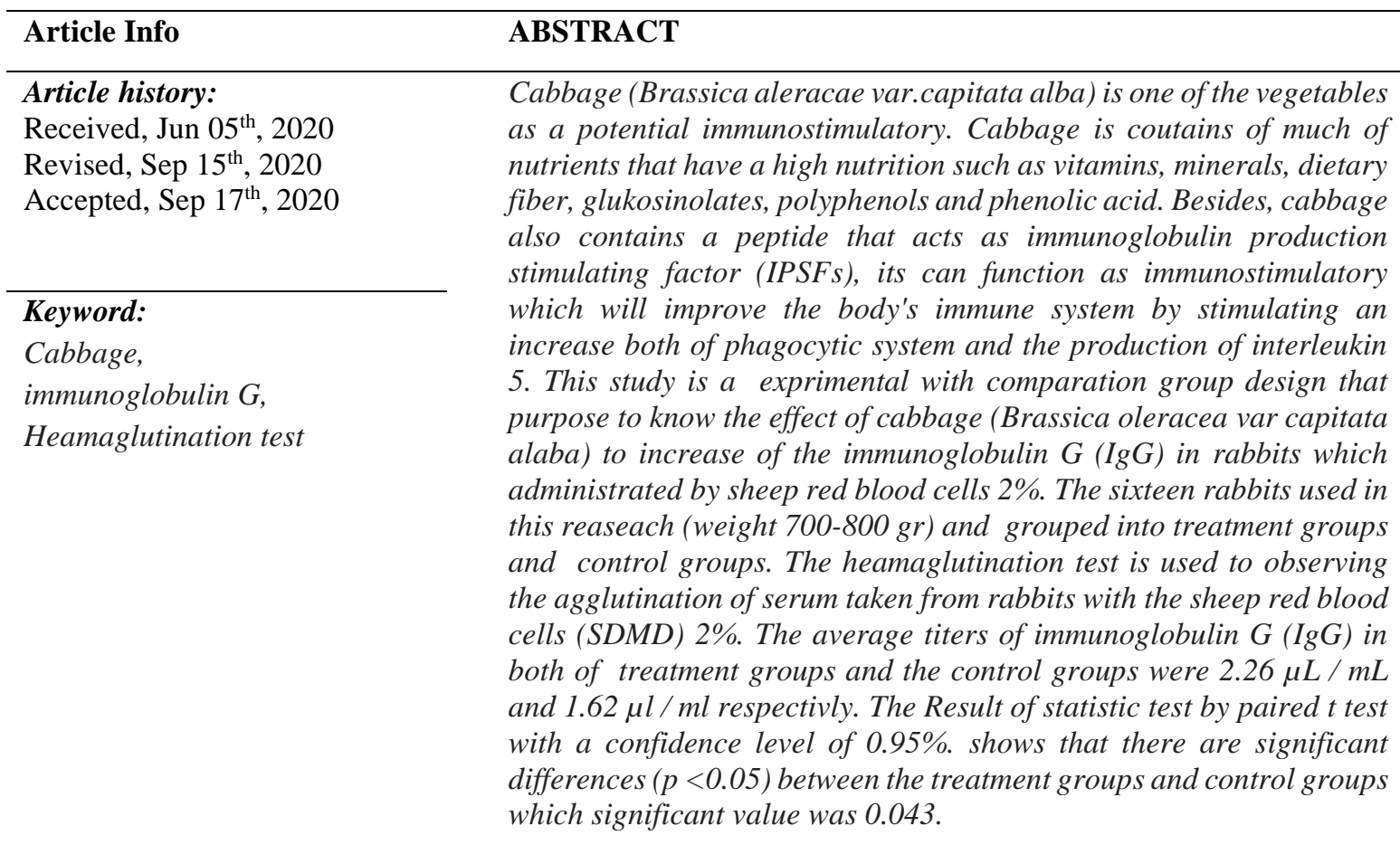

Copyright $@$ Jurnal Analis Medika Biosains (JAMBS)

All rights reserved

\begin{abstract}
ABSTRAK
Kubis (Brassica aloracae var.capitata alba) adalah salah satu sayuran yang berpotensi sebagai imunostimulator. Kubis banyak megandung nutrien yang mempunyai nutrisi tinggi seperti vitamin, mineral, dietary fiber, glukosinolates, polyphenol dan phenolic acid. Disamping itu juga kubis mengandung peptida yang berperan sebagai imunoglobulin production stimulating factor (IPSF) sehingga dapat berfungsi sebagai imunostimulator yang akan dapat meningkatkan sistem imun tubuh dengan cara merangsang peningkatan sistem fagositik dan produksi interleukin 5. Penelitian ini merupakan penelitian ekprimental dengan desain statistic group comparation yang bertujuan mengetahui pengaruh pemberian kubis (Brassica oleracea capitata alba) untuk meningkatkan pembentukan immunoglobulin $\mathrm{G}$ (IgG) pada kelinci yang diinduksi dengan sel darah merah domba $2 \%$. Hewan coba yang digunakan dikelompokkan menjadi 2 kelompok yaitu kelompok perlakuan dan kelompok kontrol. Hewan coba yang digunakan adalah kelinci dengan berat 700800 gr sebanyak 16 ekor dibagi menjadi dua kelompok yaitu kelompok perlakuan dan kontrol. Metode pemeriksaan yang digunakan adalah dengan uji heamaglutinasi dengan mengamati terjadinya aglutinasi antara serum yang diambil dari darah kelinci dengan sel darah merah domba (SDMD) $2 \%$. Rata-rata titer Imunoglobulin $\mathrm{G}$ (IgG) pada kelompok perlakuan dan kelompok kontrol masing-masing adalah $2.26 \mu 1 / \mathrm{ml}$ dan $1.62 \mu \mathrm{l} / \mathrm{ml}$. Hasil uji statistik dengan paired t test dengan tingkat kepercayaan $0,95 \%$ menunjukkan bahwa terdapat perbedaan yang signifikan $(p<0,05)$ antara kelompok perlakuan dan kelompok kontrol yaitu dengan nilai signifikan 0,043 .
\end{abstract}

Kata Kunci : Kubis, Imunoglobulin G, Heamaglutinasi Test 


\section{Pendahuluan}

Lingkungan mengandung bermacam-macam agen infeksi seperti virus, bakteri, jamur dan parasit. Banyaknya agen infeksi yang terdapat pada lingkungan dapat mengakibatkan penyakit infeksi bahkan kematian jika penyebarannya tidak dihambat. Sistem imun bekerja melindungi tubuh dari infeksi oleh mikroorganisme, membantu proses penyembuhan dalam tubuh dan membuang atau memperbaiki sel-sel yang rusak. Mikroorganisme yang masuk dalam tubuh akan merusak jaringan tubuh dengan menghasilkan toksin atau zat-zat lain dan dapat mempengaruhi fungsi sistem imun dengan menghambat fungsi fagositosis sehingga mengakibatkan terjadinya penurunan sistem imun (Hendarsula, 2011).

Pada individu normal paparan mikroorganisme patogen dapat dilawan dengan sistem imun tubuh, hal ini berhubungan dengan peran yang ditunjukkan oleh fungsi dan jumlah sel imun yang memadai di dalam tubuh. Kondisi lingkungan dan gaya hidup pada saat ini seperti stres, pola makan tidak sehat, kurang berolah raga, dan polusi udara yang semakin meningkat dapat mengakibatkan penurunan sistem imun tubuh sehingga dapat memicu terjadinya gangguan respon imun secara adekuat (Subowo, 2010). Faktor - faktor tersebut dapat menyebabkan mudahnya agen infeksi masuk dalam tubuh sehingga dapat menimbulkan penyakit seperti flu, diare, batuk, dan penyakit-penyakit lain seperti pneumonia (Guyton dan Hall, 1996) sehingga diperlukan peningkatan sistem imunitas tubuh.

Peningkatan imunitas dapat dilakukan dengan cara memperbaiki fungsi sistem imun menggunakan bahan-bahan yang dapat merangsang sistem imunitas atau imunostimulator. Imunostimulan dapat memperkuat ketahanan tubuh secara alamiah terhadap infeksi oleh mikroorganisme. Imunostimulan bekerja dengan cara menstimulasi sistem imun tubuh melalui fagositosis, sistem komplemen, sekresi antibodi, pelepasan interferon, sintesis antibodi oleh sel B dan melalui produksi sitokin oleh sel-sel imun (Petrunov et al, 2007).

Pemanfaatan obat-obat herbal pada saat ini sebagai imunostimulator semakin banyak dikembangkan. Menurut Wagner (1990) terdapat dua kelas senyawa yang memiliki aktivitas imunostimulasi potensial. Kelas pertama terdiri dari senyawa alkaloid, terpenoid, kuinon dan senyawa fenolik sederhana, sedangkan kelas kedua terdiri dari polisakarida, peptida, glukoprotein dan nukleotida. Senyawa-senyawa kimia yang dapat meningkatkan aktivitas sistem imun seperti senyawa fenolik, alkaloid dan terpen sangat membantu untuk mengatasi penurunan sistem imun dan senyawa-senyawa tersebut dapat diperoleh dari tumbuhan atau 
sayuran (Kumar et al, 2011). Salah satu jenis sayuran yang berpetensi sebagai imunostimulator adalah kubis (Brassica oleracea var.capitata alba ).

Kubis merupakan tanaman sayuran yang termasuk dalam keluarga tanaman kubiskubisan (Cruciferae). Kubis mempunyai peran yang sangat penting bagi kesehatan karena mempunyai nilai nutrisi yang sangat tinggi. Kubis mengandung vitamin, mineral, dietery fibers, glukosinolates, polyphenol, dan phenolic acid yang sangat dibutuhkan tubuh (Marliah, 2013). Beberapa vitamin, flavonoids dan phenolic acid berperan sebagai antioksidan sehingga mampu menjaga tubuh dari radikal-radikal bebas. Kandungan vitamin $\mathrm{C}$ yang tinggi dalam kubis dapat menjaga dan memperkuat sistem imun tubuh. Menurut penelitian yang dilakukan oleh Nishi, et al (2011) kubis mengandung peptida yang dapat meningkatkan produksi imunoglobulin M dan imuglobulin G pada sel Hibrid HB4C5 secara invitro. Imunoglobulin production-stimulating faktor ( IPSF ) yang terdapat pada kubis dapat meningkatkan proliferasi sel $\mathrm{T}$ dan fagositosis makrofage serta merangsang sekresi Interleukin-5 yang berfungsi memacu Limfosit B menghasilkan antibodi.

Berdasarkan latar belakang diatas, maka perlu dilakukan penelitian mengenai efek imunostimulator kubis (Brassica aloeceae var. capitata alba) terhadap titer imunoglobulin $\mathrm{G}(\mathrm{IgG})$ pada kelinci yang diinduksi dengan sel darah merah domba.

\section{Metode Penelitian}

Penelitian ini merupakan penelitian ekprimental, yaitu melakukan perlakuan atau intervensi terhadap suatu variabel yang akan dapat memberikan pengaruh terhadap variabel yang lain. Desain penelitian ini adalah perbandingan kelompok statik (static group comparation) yaitu memberikan perlakuan atau intervensi pada kelompok eksperimen kemudian dilakukan pengukuran dan dibandingkan dengan kelompok kontrol yang tidak diberikan intervensi (Notoatmodjo, 2010). Penelitian ini mendapat persetuan dari komisi etik penelitian kesehatan Universitas Mataram dengan No. 82/UN18.8/ETIK/2016. Pada penelitian ini intervensi dilakukan pada penelitian dengan memberikan makanan kubis (Brasicca oleraceae var capitata alba) terhadap pembentukan titer imunoglobulin $\mathrm{G}(\mathrm{IgG})$ pada kelinci yang diinduksi dengan sel darah merah domba.

Alat dan bahan yang digunakan dalam penelitian ini adalah pipet ukur, tabung reaksi $10 \mathrm{ml}$, Jarum suntik $1 \mathrm{ml}$ dan $3 \mathrm{ml}$, beker gelas, incubator, centrifuge,. Bahan yang digunakan 

var capitata alba ), dan kelinci.

Pembuatan suspensi darah merah 2\% (SDM 2\%). Sebanyak $1 \mathrm{ml}$ darah domba ditampung dalam tabung yang bersih dan berisi EDTA $1 \mathrm{mg}$, kemudian dilakukan sentrifugasi dengan kecepatan $1500 \mathrm{rpm}$ selama 15 menit. Dipisahkan antara sel dan plasmanya. Sel darah yang didapatkan selanjutnya dicuci 3 kali dengan PBS. Sel darah merah domba $100 \%$ ditambahkan PBS dengan volume yang sama banyak (konsentrasi SDMD $50 \%$ ). Selanjutnya sebanyak 0,4 $\mathrm{ml}$ SDMD $50 \%$ diencerkan dengan 9,6 ml PBS, sehingga diperoleh suspensi SDMD $2 \% \mathrm{v} / \mathrm{v}$.

Hewan uji yang digunakan pada penelitian ini adalah 16 ekor kelinci dengan berat 700 - 800 gr yang dibagi menjadi dua kelompok yaitu kelompok perlakuan dan kontrol. Kelinci diimunisasi secara intraperitonial dengan SDMD 2\% sebanyak 2 ml, kemudian dilakukan boster setiap minggu selama 3 minggu dengan SDMD 2\% masing-masing sebanyak $1 \mathrm{ml}$. Pada minggu pertama setelah dilakukan imunisasi dengan SDMD $2 \%$ kelinci kelompok perlakuan diberikan pakan kubis sebanyak 80 gr setiap harinya selama 4 minggu, sedangkan kelinci kelompok kontrol hanya diberikan pakan sayuran selain kubis ( Brasicca oleraceae var capitata alba). Pada minggu ke 4 dilakukan pengambilan darah melalui vena cubiti, kemudian darah dibiarkan membeku selama 2 jam lalu disentrifus dengan kecepatan 3000 rpm selama 10 menit dan dipisahkan serumnya untuk pemeriksaan uji heamaglutinasi.

Uji heamaglutinasi. Serum dari masing-masing kelompok perlakuan diencerkan secara double dilution dengan PBS dari 1/2, 1/4, 1/8, 1/16, sampai 1/512. Dipipet sebanyak $50 \mu \mathrm{l}$ dari masing-masing pengenceran ke mikro well, kemudian masing-masing ditambahkan $50 \mu 1$ suspensi SDMD $2 \%$ dan dihomogenkan selama 5 menit. inkubasi selama 60 menit pada suhu $37^{\circ} \mathrm{C}$, kemudian dibiarkan pada suhu kamar selama 24 jam. Diamati terjadinya heamaglutinasi pada pengenceran tertinggi dari masing-masing perlakuan (Lantapi, et al.,2011).

Data yang diperoleh adalah hasil pengenceran tertinggi serum darah kelinci yang masih menunjukkan aglutinasi dengan sel darah merah domba. Hasil pembacaan titer pada masing-masing perlakuan dikonversi dengan rumus $(2 \log ($ titer $)+1)$, kemudian dianalisa secara statistik dengan mengunakan uji beda (paired t test) untuk mengetahui beda nyata antara kelompok perlakuan dan kontrol dengan tingkat kepercayaan $95 \%$. 


\section{Hasil Dan Pembahasan}

Titer hasil uji heamaglutinasi untuk mengetahui aktivitas imunoglobulin G (IgG) pada kelinci yang diberikan pakan kubis dan yang tidak diberikan pakan kubis masingmasing kelompok perlakuan terlihat seperti pada tabel 1 sebagai berikut :

Tabel 1. Hasil Heamaglitinasi masing-masing kelompok perlakauan

\begin{tabular}{|c|c|c|c|c|c|}
\hline \multirow{2}{*}{ No } & \multicolumn{2}{|c|}{$\begin{array}{l}\text { Titer masing-masing kelompok } \\
\text { perlakauan (pengenceran ) }\end{array}$} & \multicolumn{2}{|c|}{$\begin{array}{c}\text { Konversi } \\
(2 \log \mathrm{P}+1) \\
\end{array}$} & \multirow[t]{2}{*}{ Sig } \\
\hline & Kelompok 1)* & Kelompok 2)** & Kelompok 1)* & $\begin{array}{l}\text { Kelompok } \\
2)^{* *}\end{array}$ & \\
\hline 1. & $1 / 8$ & $1 / 2$ & 2.80 & 1.60 & \\
\hline 2. & $1 / 2$ & $1 / 2$ & 1.60 & 1.60 & \\
\hline 3. & $1 / 4$ & $1 / 4$ & 2.20 & 2.20 & \\
\hline 4. & $1 / 4$ & $1 / 2$ & 2.20 & 1.60 & $0.043 * * *$ \\
\hline 5. & $1 / 8$ & $1 / 4$ & 2.80 & 2.20 & \\
\hline 6. & $1 / 4$ & $1 / 4$ & 2.20 & 2.20 & \\
\hline 7. & $1 / 2$ & $1 / 2$ & 1.60 & 1.60 & \\
\hline 8. & $1 / 4$ & $1 / 2$ & 2.20 & 1.60 & \\
\hline 9. & $1 / 4$ & $1 / 2$ & 2.20 & 1.60 & \\
\hline 10. & $1 / 8$ & 0 & 2.80 & 0 & \\
\hline \multicolumn{3}{|c|}{ Rata-rata } & 2.26 & 1.62 & \\
\hline
\end{tabular}

Keterangan : )* : kelinci yang diberikan pakan kubis

)** : kelinci yang tidak diberikan pakan kubis

$* * *$ : signifikan $<0.05$

$\mathrm{p}$ : pengenceran

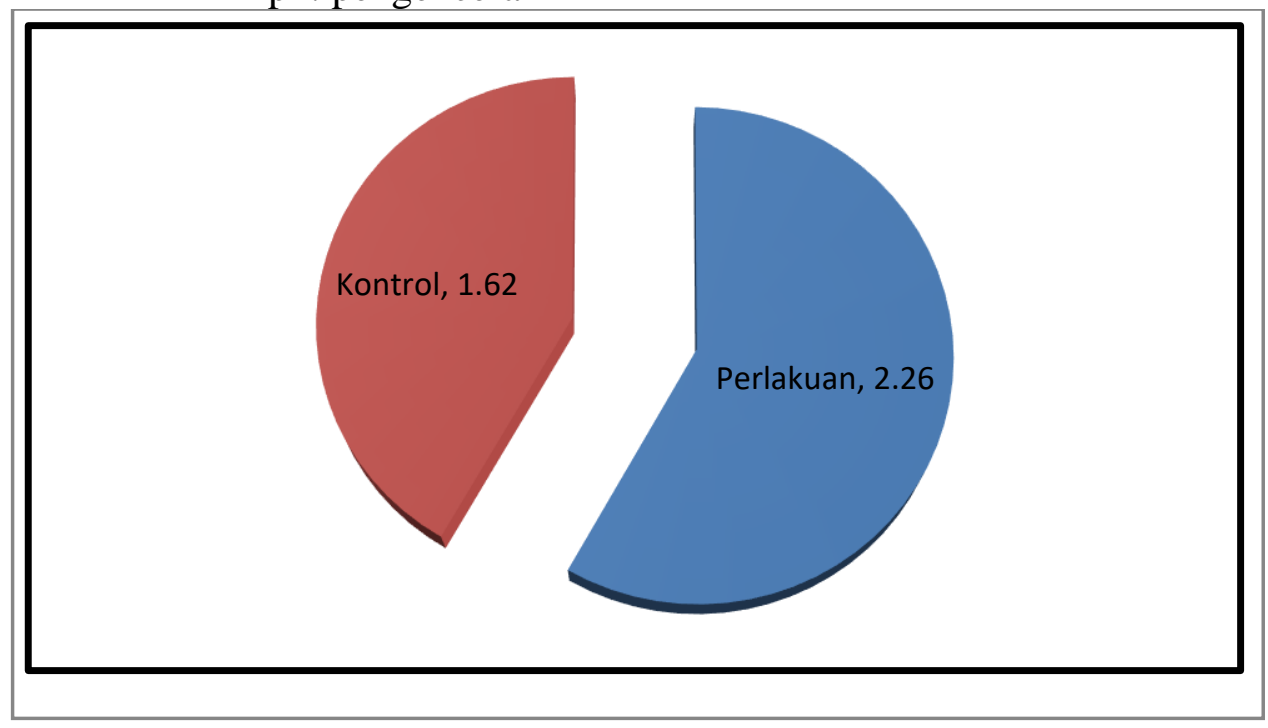

Gambar 1. Perbandingan Rata-rata titer IgG yang dihasilkan oleh kelinci pada kelompok perlakuan dan kontrol 


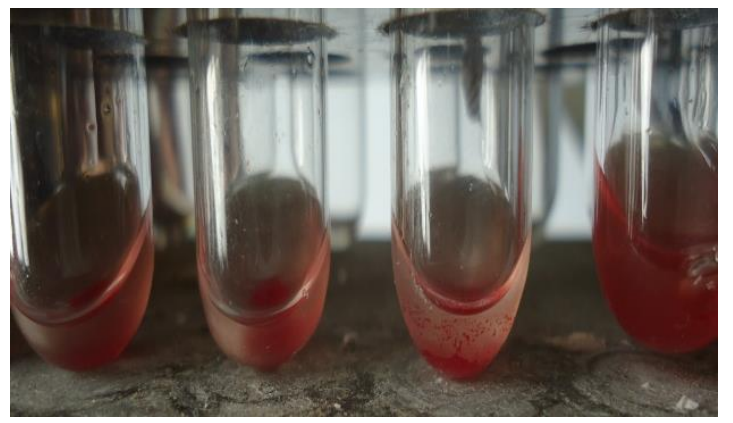

$1 / 2 \quad 1 / 4$

Pos (+) Pos $(+)$

$1 / 8$

$1 / 16$

Gambar 2. Hasil Heamaglutinasi pada

Kelinci yang diberi pakan kubis (Brasicca oleracea var.capitata alba )

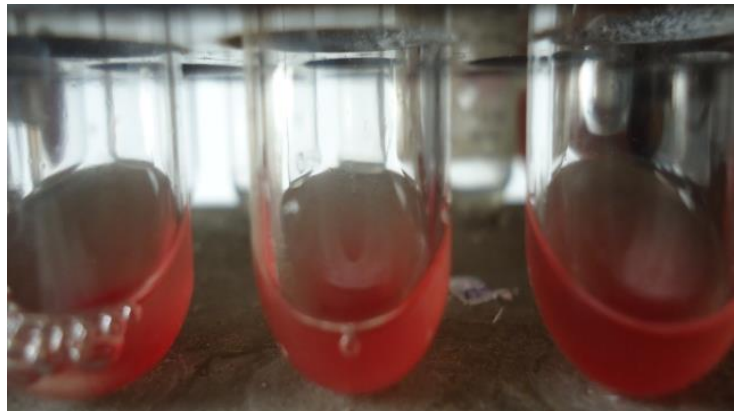

$1 / 2$

$1 / 4$

$1 / 8$

Pos (+)

$\operatorname{Neg}(-)$

Neg (-)

Gambar 3. Hasil Heamaglutinasi pada kelinci yang tidak diberikan pakan kubis (Brasicca oleracea var.capitata alba)

Kubis ( Brassica oleraceae var.capitata alba ) merupakan sayuran yang sehari-hari dikonsumsi masayarakat dalam bentuk bunga sebagai bunga kol dan kembang kol atau dalam bahasa asing disebut cauliflower. Bagian yang dikonsumsi dari sayuran ini adalah masa bunganya (curd). Masa kubis bunga umumnya berwarna putih bersih. Kubis mempunyai peranan penting bagi kesehatan manusia, karena mengandung vitamin dan mineral yang sangat dibutuhkan tubuh. Kandungan protein maupun karbohidarat dalam bentuk serat yang terdapat pada kubis ini dapat berfungsi sebagai imunostimulator (Marliah, et al.,2013)

Imunostimulator adalah bahan yang dapat meningkatkan kerja komponenkomponen sistem imun baik komponen imun spesifik dan nonspesifik. Kedua jenis sitem imun tersebut bekerja sama untuk menjaga ketahanan tubuh dari masuknya bahan asing (antigen) yang dapat berasal dari bakteri, virus maupun protozoa. Perlindungan oleh sistem imun dapat berupa perlindungan seluler maupun humoral seperti terbentuknya antibodi atau imunoglobulin (Lantapi, et al., 2011). Immunoglobulin (antibodi) merupakan molekul yang dihasilkan oleh limfosit B. Antigen yang digunakan untuk induksi produksi antibodi pada penelitian ini adalah sel darah merah domba (SDMD) yang merupakan imunogen, yaitu antigen yang berasal dari gen spesies lain. SDMD merupakan antigen polivalen yang merupakan protein dengan determinan potensial yang lebih besar dibandingkan dengan antigen monovalen. Semakin asing antigen yang digunakan, semakin efektif antigen tersebut 
menimbulkan respon imun. Antigen ini diinjeksikan ke tubuh kelinci secara intraperitoneal sebelum diberikan perlakuan. Imunisasi ini dimaksudkan untuk memberikan respon imun pada hewan coba. Setelah diinjeksikan SDMD kelinci selanjutnya diberikan perlakuan dengan pakan kubis dan kelompok kontrol tidak diberikan pakan kubis.

Pada hari ke 21 setelah induksi SDMD, darah kelinci diambil secara intravena mealui telinga untuk mengamati aktivitas IgG. Selama kurun waktu tersebut, diharapkan telah terjadi sensitasi sel B yang akan berproliferasi, berdiferensiasi dan berkembang menjadi sel plasma yang memproduksi antibodi yaitu IgM dan IgG. IgM merupakan imunoglobulin yang pertama kali diproduksi sebagai respon imun terhadap antigen yang diikuti pengalihan ke produksi IgG atau antibodi kelas lain. Hal ini tergantung dari sinyal sel Th yang memerlukan ikatan dengan ligan CD40 (CD154) di permukaan sel T, dan dengan CD40 di sel B. Di samping itu, sitokin yang diproduksi sel $\mathrm{T}$ berpengaruh terhadap gen regio konstan yang menimbulkan pengalihan kelas antibodi (Abbas et al, 2007)

Hewan coba yang digunakan adalah kelinci jantan karena tidak dipengaruhi oleh siklus hormonal, yang dapat mempengaruhi hasil penelitian. Hasil penelitian dipengaruhi juga oleh variasi biologik hewan coba, misalnya jenis, berat bobot badan, umur, jenis kelamin, dan kondisi lingkungan. Pengujian terhadap serum darah kelinci dilakukan dengan menambahkan antigen yang sama yaitu sel darah merah domba. Interaksi antara antigen dengan antibodi menyebabkan terjadinya reaksi sekunder, yaitu berupa aglutinasi atau presipitasi sebab antigen merupakan partikel-partikel kecil yang tidak larut. Gumpalan yang terbentuk antara antigen dan anti serum spesifik akan bersatu dan akhirnya mengendap sebagai gumpalan-gumpalan besar dan mudah terlihat dengan cairan di atasnya tetap jernih. Hal ini terjadi karena pada umumnya antibodi memiliki lebih dari satu reseptor pengikat antigen sehingga antibodi bereaksi dengan molekul antigen lain yang mungkin sudah berikatan dengan salah satu molekul antibodi dan terbentuklah gumpalan (Lantapi et al, 2011).

Pencampuran serum dengan antigen dibuat dalam pelarut $\mathrm{PBS}(\mathrm{NaCl}$ dalam buffer fosfat) dengan $\mathrm{pH} 7,2$ yang dianggap baik adalah $\mathrm{pH}$ netral, yaitu antara $6-7,5 . \mathrm{pH}$ sebaiknya tidak kurang dari 6 dan tidak lebih dari 8,6 karena dapat menyebabkan kompleks antigen-antibodi mudah berdisosiasi sehingga tidak terjadi aglutinasi. Selanjutnya, dilakukan pengadukan ("shaker") serta inkubasi selama 1 jam sebelum dibiarkan selama 1 kali 24 jam pada suhu kamar. Hal ini dilakukan karena reaksi aglutinasi baru dapat terjadi 
bila rasio antara antigen dan antibodi seimbang, sehingga terbentuk zona ekuivalen, dibantu oleh suhu yang tinggi $\left(37-56^{\circ} \mathrm{C}\right)$ dan oleh gerakan yang menambah kontak antigen dan antibodi (misalnya mengocok, mengaduk dan memutar) serta berkumpulnya gumpalan memerlukan garam-garam yang berasal dari PBS yang digunakan. Pengamatan aktivitas imunoglobulin dilakukan dengan melihat titer antibodi yaitu pengenceran tertinggi dari larutan yang masih menunjukkan reaksi heamaglutinasi. Hasil perhitungan dengan mengkonversi nilai titer antibodi dengan rumus $[2 \log ($ titer $)+1]$. Hasil konversi titer antibodi terlhat pada tabel 1 .

Berdasarkan analisis statistik dengan menggunakan paired t test dengan tingkat kepercayaan $95 \%$ memperlihatkan bahwa Imunoglobulin G (IgG) yang dihasilkan oleh kelinci terjadi perbedaan yang signifikan (t hitung lebih kecil dari 0,05) diantara kelompok perlakuan dan kelompok kontrol. Dari hasil ini berarti terjadi peningkatan aktivitas imunoglobulin $\mathrm{G}(\operatorname{IgG})$ dengan pemberian pakan kubis pada kelinci. Kandungan dietery fibers, glukosinolates, dan lectin yang terdapat pada kubis dapat berperan sebagai adjuvan sehigga dapat meningkatkan pembentukan antibodi oleh sel B.

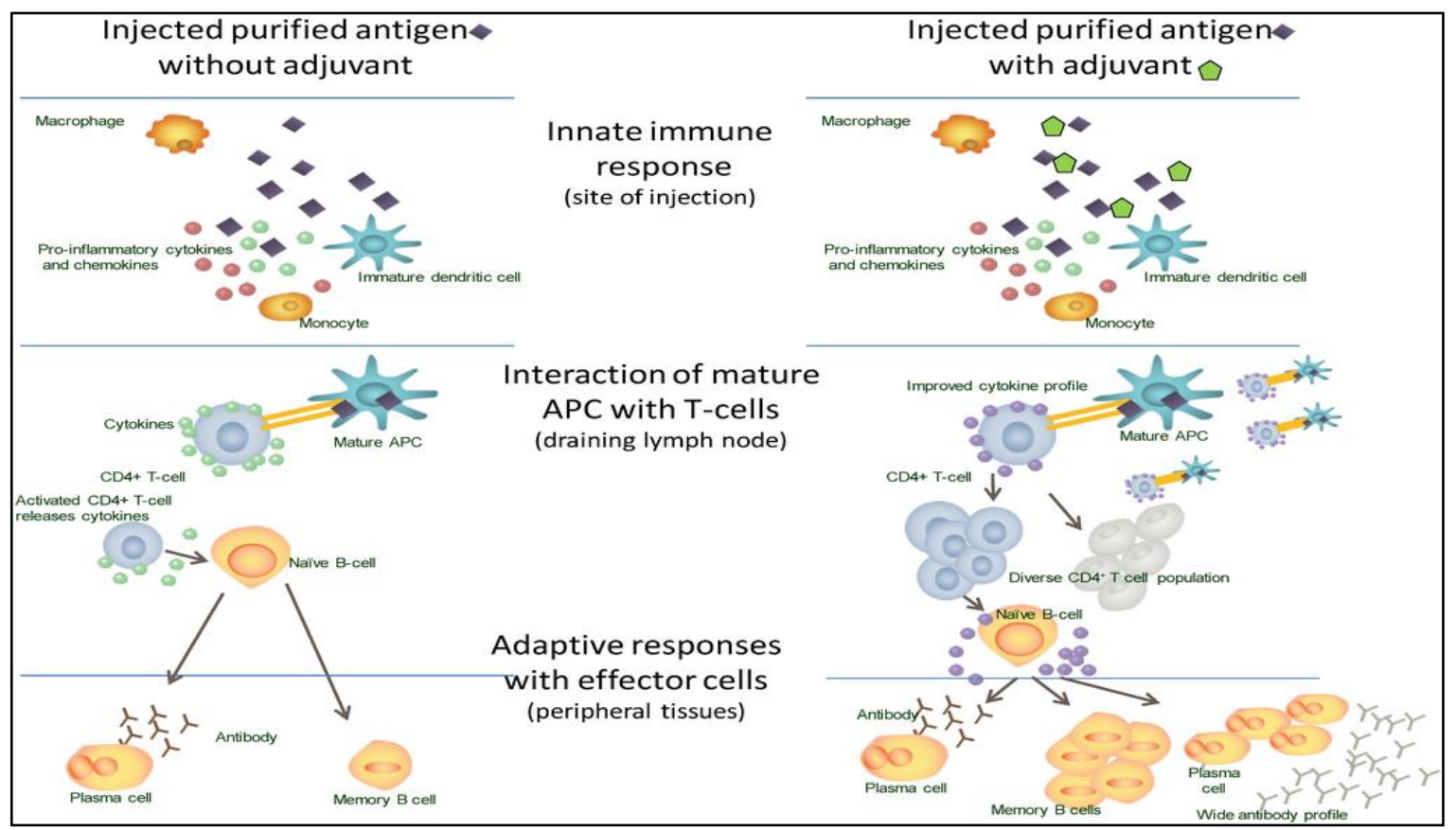

Gambar 4. Peranan adjuvan dalam meningkatkan respon imunitas (sumber : Di pasquale et al., 2015 ) 
Perlakuan ke 10 pada kelompok kontrol pada tabel 1 menunjukkan tidak ditemukan adanya aktivitas IgG, hal ini kemungkinan disebabkan karena jumlah antigen (SDMD) yang disuntikkan tidak mampu merangsang terbentuknya antibodi. Pembentukan antibodi dapat dipengaruhi oleh banyaknya antigen atau terjadi mekanisme toleran pada mencit sehingga tidak mampu menghasilkan antibodi. Pada tabel 1 juga terlihat adanya peningkatan aktivitas imunoglobulin imunoglobulin $\mathrm{G}(\mathrm{IgG})$ pada kelompok perlakuan bila dibandingkan dengan kelompok kontrol yaitu rata-rata Imunoglobulin $\mathrm{G}(\mathrm{IgG})$ pada kelompok perlakuan dan kontrol masing-masing adalah 2.26 dan 1.62. Hal ini diduga karena adanya senyawa aktif dari kubis sebagai imunostimulator. Hal ini telah dibuktikan oleh penelitian yang dilakukan oleh Nishi et al. Penelitian yang dilakukan oleh Nishi et al, (2011) menunjukkan bahwa Kubis (Brasicca oleracea L. var achepela DC) mengandung suatu subtansi dengan berat molekul 50 Kda yang diidentifikasi sebagai ribulosa 1-5-biphosfate carboxylase (rubisco). ribulosa 1-5-biphosfate carboxylase merupakan protein yang sangat stabil terhadap pemansan dan berperan dalam menstimulasi sel hibridoma HB4C5 untuk menghasilkan imunoglobulin. Penambahan extrak pada media kultur HB4C5 dapat meningkatkan produksi Imunoglobulin $\mathrm{M}$ dan IgG sampai 5 kali lipat bila dibandingkan dengan kontrol. Imunoglobulin Protein-Stimulating Faktor (IPSFs) pada kubis dapat merangsang sel untuk menghasilkan IL-5 yang merupakan sinyal transduksi untuk meningkatkan produksi imunoglobulin pada sel B.

\section{Kesimpulan}

Dari hasil penelitian yang diperoleh, disimpulkan bahwa terdapat berbedaan yang sinifikan $(p<0,05)$ antara kelompok perlakuan dan kelompok kontrol setelah dilakukan uji statistik dengan paired t test, dimana pemberian pakan kubis (Brasicca oleraceae var capitata alba) pada kelinci dapat meningkatkan pembentukan Imunoglobulin G (IgG).

\section{Daftar Pustaka}

Abbas, A,K., Lichtman, A,H., Pillai, S., 2007, Celluler and Moleculer Imunology, sixth Edition, Saunder.

Di Pasquale, A., Preiss, S., Tavares Da Silva, F., \& Garçon, N. 2015. Vaccine Adjuvants: from 1920 to 2015 and Beyond. Vaccines, 3(2), 320-343. http://doi.org/10.3390/vaccines3020320 
Guyton, A, C.,1996. Buku Ajar Fisiologi Edisi Tujuh Vol.12.No.3. Alih Bahasa, Tengadi, dkk. Jakarta: EGC. .

Hendarsula, A,R., 2011, Uji Aktivitas imunostimulan ekstrak etanol umbi sarang semut (Myrmecodia archboldiana Merr.\&L,M,Perry) Pada putih jantan. Skripsi. FMIPA Universitas Indonesia.

Kumar, S., Gupta, P., Sharma, S., and Kumar, D. 2011. A review on imunostimulatory plants, Review. Journal of Chinese Integrative Medicine. 9(2): 117 - 128

Lantapi, N,C., Manggau, M,A., Alam, G., 2011, Uji efek jus buah mengkudu (Morinda citrifolia Linn) terhadap aktivitas immunoglobulin $\mathrm{M}$ dan immunoglobulin $\mathrm{G}$ pada mencit (Mus musculus), Majalah farmasi dan farmakologi. Vol 15(2): 99- 104.

Marliah A, Nurhayati, Riana, R. 2013. Pengaruh varietas dan konsentrasi pupuk majemuk terhadap pertumbuhan daun dan hasil tanaman kubis bunga (Brassica oleracea L). $j$. floratek. 8:118-126.

Notoatmodjo, S., 2010, Metodologi penelitian kesehatan, PT.,Rineka Cipta, Jakarta.

Nishi, K., Kondo, A., Okamoto, T., et al., 2011, Imunostymulatory in vitro and in vivo effects of a water-soluble extract from kale, Biosci. Biotecnhol Biochem. 75(1): 4046

Petrunov, B., Nenkov, p., and Shekerdjiisky, R., 2007,The Role of Immunostimulants In Immunotherapy and Immunoprophylaxix, Bulgaria: National Center of Infectious and Parasitic Diseases, Bulbio-NCIPD, Natsim Ltd.

Subowo., 2010, Imunologi Klinik, Sugeng Seto, Jakarta. 